\title{
PEMANFAATAN KULIT UDANG (Penqeus modonon) UNTUK PEMBUATAN KITOSAN SEBAGAI PENGAWET ALAMI DAGING
}

\author{
Nikman Azmin ${ }^{1}$, Muh. Nasir ${ }^{2}$, Hartati ${ }^{3}$ \\ ${ }^{123}$ Dosen Sekolah Tinggi Keguran dan Ilmu Pendidikan (STKIP) Bima \\ Email: biologinikman@gmail.com
}

\begin{abstract}
Abstrak: Kitosan secara komersil umumnya diekstraksi dari kulit udang yang diperoleh dari limbah industri. Proses ekstraksi kitosan dari kulit udang merupakan proses reaksi kimia yang sederhana secara alternatif untuk menggantikan proses ekstraksi kimia kitosan yaitu dengan cara fermentasi menggunakan mikroorganisme bakteri proteolitik atau bakteri asam laktat. Penelitian ini bertujuan untuk mengetahui pengaruh konsentrasi basah $\mathrm{NaOH}$ pada proses deproteinasi terhadap kitosan kotor yang dihasilkan dari kulit udang dan mengetahui pengaruh perbandingan kitosan bersih serta $\mathrm{NaOH}$ pada proses deasetilasi terhadap kitosan yang dihasilkan dari kulit udang. Penelitian ini dilakukan di Laboratorium Matematika Ilmu Pengetahuan Alam (MIPA) Fakultas MIPA Jurusan Kimia Universitas Sebelas Maret Surakarta, mulai bulan Juni 2014 sampai Agustus 2014. Metode penelitian yang digunakan adalah metode eksperimen. Hasil penelitian menunjukan bahwa pada proses deproteinasi dengan konsentrasi pelarut 2,5 N dihasilkan kitosan kotor seberat 32,5572 gram dengan perbandingan 1:15 (kitosan bersih:pelarut) dan menghasilkan kitosan seberat 4,2511 gram. Perbandingan yang optimum untuk pengawetan daging adalah 14:5 gram daging/ml larutan pengawet) dengan lama pengawetan 72 jam
\end{abstract}

\section{Kata Kunci: Kitosan, Cangkang Udang, Pengawet Alami.}

\section{PENDAHULUAN}

Akhir-akhir ini hampir semua masyarakat Indonesia mengalami rasa was-was untuk mengkonsumsi makanan, khususnya makanan basah seperti mie, daging dan kemudian bertambah luas kekhawatiran itu, yakni takut mengkonsumsi ikan segar dan ikan yang diasinkan. Padahal ikan segar maupun yang diasinkan selama ini merupakan sumber protein yang sangat dibutuhkan oleh manusia. Namun, oleh karena penggunaan formalin dan bahan pengawet kimia lainnya mulai menguat, sehingga ketakutan pun menebar di seluruh nusantara. Penyebab dari semua kekhawatiran tersebut tidak lain karena terdapat kandungan berbahaya (racun) yang berupa formalin. Formalin yang biasanya digunakan sebagai pengawet mayat, tapi digunakan untuk pengawet makanan. Padahal ada pengawet makanan yang aman dikonsumsi dan bersifat alami yakni kitosan Hardjito (2009). Bahan pengawet ini banyak terdapat dalam kulit luar hewan golongan Crustaceae seperti udang, rajungan, cumi dan kepiting Yunizal et al (2001)

Bahan pengawet merupakan bahan tambahan makanan yang dibutuhkan untuk mencegah aktivitas mikroorganisme ataupun 
mencegah proses peluruhan yang terjadi sesuai dengan pertambahan waktu, agar kualitas makanan senantiasa terjaga sesuai dengan harapan konsumen. Dengan demikian pengawet diperlukan dalam pengolahan bahan makanan, namun kita harus tetap mempertimbangkan keamanannya. Hingga kini, penggunaan pengawet yang tidak sesuai masih sering terjadi dan sudah semakin luas, tanpa menghiraukan dampaknya terhadap kesehatan konsumen Hayashi (2011)

Limbah udang, kepiting, cumi, rajungan dan sejenis crustaceae lainnya dapat dimanfaatkan sebagai bahan pengawet alami karena mengandung kitin. Tapi di antara jenis crustaceae, yang paling banyak kandungan kitinnya adalah limbah kulit udang. Limbah udang yang mencapai 30-40 \% dari produksi udang beku belum banyak dimanfaatkan. Menurut Mekawati (2012) mengatakan bahwa pemanfaatan limbah kulit udang menjadi produk udang yang bernilai ekonomis tinggi merupakan contoh yang sangat baik untuk memperoleh bahan makanan dengan kandungan protein tinggi. Selama ini kuli udang telah dimanfaatkan sebagai bahan pembuat terasi, keripik udang dan petis serta pasta udang dan hidrolisat protein yang merupakan produk jenis baru dari limbah kulit udang. Limbah kulit udang selain dimanfaatkan sebagai bahan pangan, dapat juga dipergunakan untuk keperluan industri salah satunya adalah pembuatan kitosan sebagai pengawet alami. Pembuatan kitosan dari kulit udang dapat dipakai sebagai bahan kimia untuk industri dan kertas. Kepala udang yang menyatu dengan kulit udang sebagai limbah industri udang beku dan hanya baru sebagian kecil yang dimanfaatkan, yaitu untuk pembuatan tepung sebagai pencampur bahan dalam pembuatan pellet untuk pakan ternak (Mudjiman, 1982). Kulit udang mengandung unsur yang bermanfaat yaitu protein, kalsium dan kitosan, sedangkan zat kitosan yang mempunyai kegunaan dan prospek yang baik dalam industri. Protein dan kalsium dapat digunakan sebagai bahan tambahan dalam pembuatan pakan ternak, sedang kitin dapat dimanfaatkan sebagai surfaktan, zat pengemulsi, pengawet makanan, bahan tambahan untuk antibiotika dan kosmetik Yunizal (2011)

Kitin adalah polimer alami yang melimpah di alam. Kitin merupakan senyawa kedua terbesar setelah selulosa dan dikenal juga sebagai polimer organik konversional dari laut, sedangkan Kitosan adalah modifikasi dari senyawa kitin yang banyak terdapat dalam kulit luar hewan golongan Crustaceae seperti udang, cumi, rajungan dan kepiting. Khasiat kitosan sebagai bahan antibakteri dan kemampuannya untuk mengimobilisasi bakteri menjadikan kitosan dapat digunakan sebagai pengawet makanan. Daya hambat 
kitosan terhadap bakteri tergantung dari konsentrasi pelarutan kitosan.

\section{METODE}

\section{Jenis penelitian}

Jenis penelitian ini adalah penelitian eksperimen dan pengamatan langsung di Labortorium Biologi.

\section{Alat dan Bahan}

Alat Adalah blender, Ayakan, Oven, Kertas saring, Timbangan, $\mathrm{pH}$ meter dan bahan adalah Kulit udang $5 \mathrm{~kg}$ berat basah yang diperoleh dipasar dekat Amplaz, $\mathrm{NaOH}$ 0,$5 ; 1 ; 1,5 ; 2 ; 2,5 \mathrm{~N}, \mathrm{HCl} 1 \mathrm{~N}, \mathrm{NaOH} 50 \%$ diperoleh dari CV. Cmem-mix Pratama Yogyakarta, Asam Asetat $1 \%$ diperoleh dari CV. Cmem-mix Pratama Yogyakarta, Daging dari Pasar dekat Amplaz dan Aquadest.

\section{Rancangan Penelitian}

Mengunakan cara Deproteinasi.

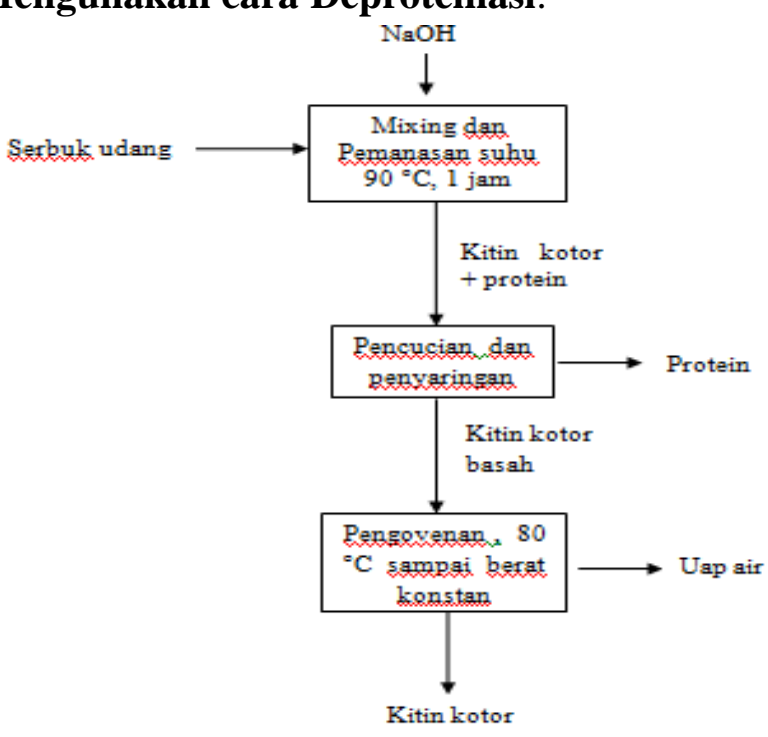

\section{Gambar 1. Rancangan Penelitian cara Deproteinasi}

\section{Mengunakan cara Demineralisasi}

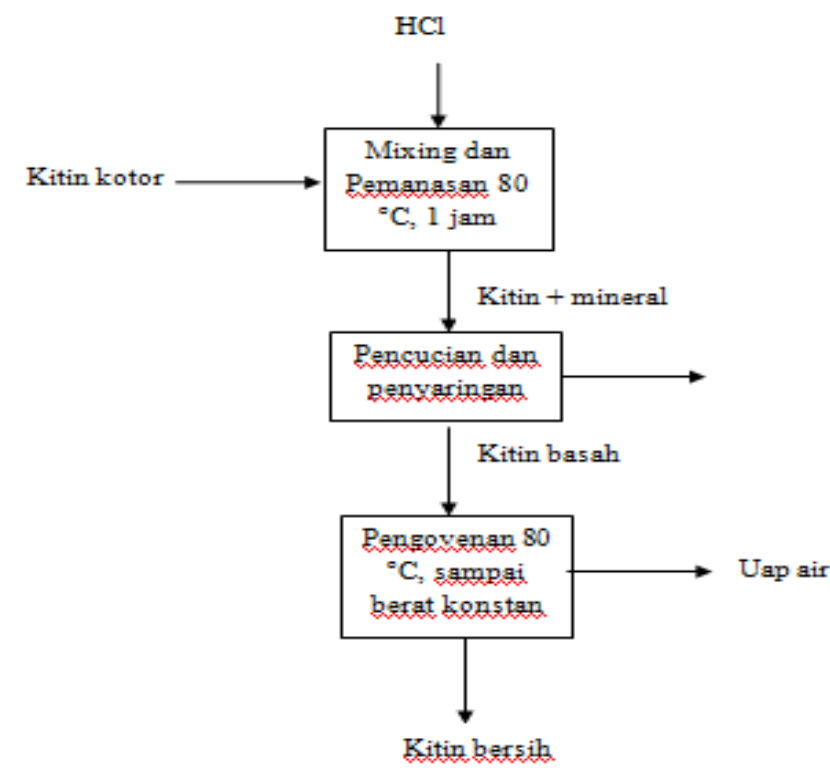

\section{Gambar 2. Rancangan penelitian cara} Demineralisasi

\section{Prosedur Penelitian}

\section{Penyiapan Bahan Baku}

Terlebih dahulu limbah cangkang udang dibersihkan dari kotoran-kotoran. Limbah cangkang udang yang telah bersih dikeringkan dengan dijemur. Limbah cangkang udang kering dihancurkan dengan blender hingga menjadi serbuk udang. Selanjutnya serbuk udang diayak dengan ayakan 32 mesh sehingga diperoleh hasil berupa serbuk udang.

\section{Proses Deproteinasi}

Proses penghilangan protein dilakukan dengan cara serbuk udang ditambahkan larutan $\mathrm{NaOH}$ dengan konsentrasi $0,5 \mathrm{~N} ; 1 \mathrm{~N}$; $1,5 \mathrm{~N} ; 2 \mathrm{~N} ; 2,5 \mathrm{~N}$ dan perbandingan 1:5 (berat:volume) dipanaskan pada suhu $90{ }^{\circ} \mathrm{C}$, sambil diaduk selama 1 jam dengan menggunakan pengaduk magnetik. Hasilnya 
disaring dan endapan yang diperoleh dicuci dengan menggunakan aquadest sampai $\mathrm{pH}$ netral. Selanjutnya dikeringkan dalam oven suhu $80{ }^{\circ} \mathrm{C}$ tiap 50 menit sampai berat konstan. Sehingga diperoleh hasil berupa kitin kotor.

\section{Proses Demineralisasi}

Proses penghilangan mineral dari kitin kotor hasil deproteinasi dilakukan dengan menambahkan larutan $\mathrm{HCl} 1 \mathrm{~N}$ dengan perbandingan 1:10 dipanaskan pada suhu 80 ${ }^{\circ} \mathrm{C}$, sambil diaduk selama 1 jam dengan menggunakan pengaduk magnetik. Hasilnya disaring dan endapan yang diperoleh dicuci dengan menggunakan aquadest sampai $\mathrm{pH}$ netral. Selanjutnya dikeringkan dalam oven suhu $80{ }^{\circ} \mathrm{C}$ setiap 50 menit sampai berat konstan. Sehingga diperoleh hasil berupa kitin bersih.

\section{Proses Deasetilasi}

Kitin bersih yang dihasilkan ditambah larutan $\mathrm{NaOH} 50 \%$ dengan perbandingan 1:5; $1: 10 ; 1: 15 ; 2: 5 ; 2: 15$ dipanaskan pada suhu $100{ }^{\circ} \mathrm{C}$, sambil diaduk selama 90 menit. Hasilnya disaring dan endapan yang diperoleh dicuci dengan aquadest sampai $\mathrm{pH}$ netral. Selanjutnya dikeringkan dalam oven pada suhu $80{ }^{\circ} \mathrm{C}$ setiap 50 menit sampai berat konstan. Sehingga diperoleh hasil berupa kitosan.

\section{Proses Pengawetan Daging}

Serbuk kitosan sebanyak 1,5 gram ditambah dengan $100 \mathrm{~mL}$ larutan asam asetat $1 \%$. Campuran diaduk selama 1 jam, kemudian disaring. $20 \mathrm{~mL}$ air hasil saringan digunakan untuk merendam daging selama 60 menit (waktu perendaman) dengan perbandingan $2: 5 ; 4: 5 ; 6: 5 ; 8: 5 ; 10: 5 ; 12: 5$; 14:5; 16:5 (gram daging : $\mathrm{mL}$ pelarut). Pengamatan dilakukan selama 4 hari berturutturut

\section{HASIL DAN PEMBAHASAN}

Hasil penelitian pada proses deproteinasi

Tabel 1. Pengaruh konsentrasi pelarut $\mathrm{NaOH}$ terhadap kitin kotor yang dihasilkan

\begin{tabular}{ccc}
\hline No & $\begin{array}{c}\text { Konsentrasi } \\
\text { pelarut } \mathbf{N a O H}(\mathbf{N})\end{array}$ & $\begin{array}{c}\text { Berat kitin kotor } \\
(\mathbf{g})\end{array}$ \\
\hline $\mathbf{1}$ & 0,5 & 26,6902 \\
$\mathbf{2}$ & 1 & 27,5158 \\
$\mathbf{3}$ & 1,5 & 27,8724 \\
$\mathbf{4}$ & 2 & 30,0311 \\
$\mathbf{5}$ & 2,5 & 32,5572 \\
\hline
\end{tabular}

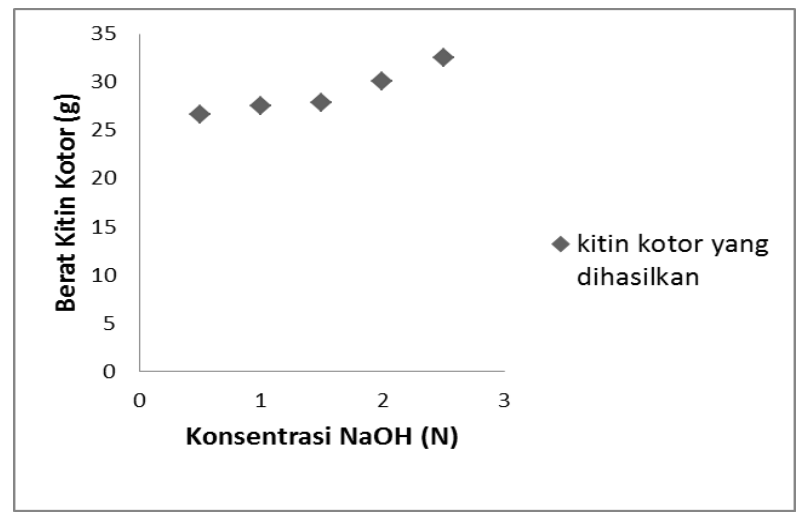

Gambar 3. Grafik Pengaruh konsentrasi pelarut terhadap kitin kotor yang dihasilkan 


\section{Proses Demineralisasi}

Kitin kotor: 32,5572 gram Rasio (berat kitin kotor : volume $\mathrm{HCl})$ : 1:10 Kecepatan motor pengaduk: 480 rpm Diperoleh berat kitin bersih : 28,6745 gram \% kitin bersih yang dihasilkan

$$
\begin{aligned}
& =\frac{\text { gram kitin bersih }}{\text { kitin kotor }} \times 100 \% \\
& =\frac{28.6745}{35.5572} \times 100 \% \\
& =80.64 \%
\end{aligned}
$$

\section{Proses Deasetilasi}

Berat kitin bersih $\quad: \pm 5$ gram, Kecepatan motor pengaduk : $480 \mathrm{rpm}$, Volume pelarut divariasi berdasarkan perbandingan $1: 5 ; 1: 10 ; 1: 15 ; 2: 5 ; 2: 15$ dengan berat kitin bersih tetap

\begin{tabular}{cc}
$\begin{array}{c}\text { Tabel 2. Perbandingan Konsentrasi pelarut } \\
\text { NaOH dengan } \\
\text { terhadap kitosan }\end{array}$ \\
\hline $\begin{array}{c}\text { Perbuk kitin } \\
\text { kitin bersih }\end{array}$ & $\begin{array}{c}\text { Berat kitosan } \\
(\mathrm{g})\end{array}$ \\
\hline $1: 5$ & 3,3531 \\
$1: 10$ & 3,9211 \\
$1: 15$ & 4,2511 \\
$2: 5$ & 3,1728 \\
$2: 15$ & 3,5745 \\
\hline
\end{tabular}

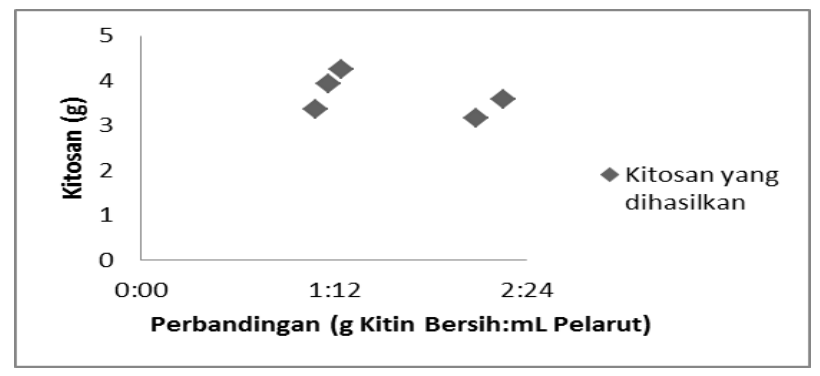

Gambar 4. Grafik pengaruh perbandingan berat kitin bersih dengan pelarut $\mathrm{NaOH} 50 \%$ terhadap kitosan yang dihasilkan

\section{Proses pengawetan Daging}

Waktu perendaman: 60 menit, Berat kitosan: 1,5 gram, volume asam asetat: 100 $\mathrm{mL}$

Pada proses pengawetan menggunakan berat daging 8-64 gram direndam dalam 20 $\mathrm{mL}$ larutan pengawet dengan perbandingan $2: 5 ; 4: 5 ; 6: 5 ; 8: 5 ; 10: 5 ; 12: 5 ; 14: 5 ; 16: 5$. Pada proses ini berat daging divariasi dengan volume pengawet tetap. Pengamatan selama 4 hari

\section{Tabel 3. Aplikasi pengawetan Daging}

\begin{tabular}{cc}
\hline $\begin{array}{c}\text { Perbandingan }(\mathrm{g} \\
\text { daging/mL pengawet) }\end{array}$ & $\begin{array}{c}\text { Lama waktu } \\
\text { pengawetan (hari) }\end{array}$ \\
\hline $2: 5$ & 3 \\
$4: 5$ & 3 \\
$6: 5$ & 3 \\
$8: 5$ & 3 \\
$10: 5$ & 3 \\
$12: 5$ & 3 \\
$14: 5$ & 3 \\
$16: 5$ & 2 \\
\hline
\end{tabular}

Proses pembuatan khitosan diawali dengan proses pendahuluan yaitu proses deproteinasi dan proses demineralisasi. Proses deproteinasi menggunakan $\mathrm{NaOH}$ sebagai pelarut dengan konsentrasi $0,5 \mathrm{~N} ; 1 \mathrm{~N} ; 1,5 \mathrm{~N}$; $2 \mathrm{~N} ; 2,5 \mathrm{~N}$ dengan volume $250 \mathrm{~mL}$ dengan berat serbuk cangkang udang 50 gram dan dipanaskan pada suhu $90^{\circ} \mathrm{C}$ selama 1 jam. Pengaruh konsentrasi pelarut terhadap kitin kotor yang dihasilkan dapat dilihat pada Tabel 1 dan Gambar 3 yaitu semakin tinggi 
konsentrasi pelarut $\mathrm{NaOH}$ maka deproteinasi makin baik. Akibatnya kitin kotor yang dihasilkan semakin banyak karena pada konsentrasi pelarut yang tinggi ikatan kitin kotorakan semakin kuat. Hasil penelitian ini didukung dengan hasil penelitian yang dilakukan Hanafi et al (2013) menyatakan bahwa Kitosan merupakan produk deasetilasi kitin melalui proses kimia menggunakan basa natrium bidroksida atau proses enzimatis menggunakan enzim chitin deacetylase yang mudah dihasilkan dari kulit udang, kepiting dan biota laut lainnya

Proses demineralisasi menggunakan kitin kotor seberat 32,5572 gram dan volume pelarut $\mathrm{HCl} 1 \mathrm{~N} 325,572 \mathrm{ml}$ menghasilkan kitin bersih seberat 28,6745 gram artinya persen kitin bersih yang dihasilkan adalah $80,64 \%$ dan sisanya merupakan senyawa mineral yang dipisahkan dari ikatan kitin kotor. Hal ini juga dikuatkan dengan pernyataan Synowiecky \& Al-Khateeb (2003) menyatakan bahwa kitin merupakan biopolimer alami yang melimpah dari kulit luar udang dan kepiting yang bisa di proses melalui demineralisasi, sehingga mendapatkan senyawa kitin

Pada proses deasetilasi menggunakan $\mathrm{NaOH} 50 \%$ sebagai pelarut dengan berbagai perbandingan (kitin:pelarut) yaitu 1:5; 1:10; $1: 15 ; 2: 5 ; 2: 15$. Suhu pemanasan $100{ }^{\circ} \mathrm{C}$ selama 90 menit. Pada Tabel 2 dan Gambar 7 terlihat bahwa pada perbandingan 1:15 menghasilkan kitosan yang banyak dan pada perbandingan 2:5 paling sedikit karena pada perbandingan 1:15 konsentrasi pelarutnya paling tinggi yaitu dengan volume $75 \mathrm{~mL}$ menyebabkan ikatan kitosan makin kuat, sedangkan pada perbandingan 2:5 konsentrasi pelarutnya terendah yaitu dengan volume 12,5 mL manyebabkan ikatan kitosan lemah.

Pada Tabel 3 dan Gambar 8 terlihat bahwa perbandingan optimum untuk pengawetan pada perbandingan 14:5 (g daging/mL pelarut), artinya dalam $20 \mathrm{~mL}$ pengawet maksimal untuk 56 gram daging. Pada konsentrasi larutan pengawet dengan perbandingan tersebut mampu memusnahkan mikroba-mikroba penyebab rusaknya daging. Untuk perbandingan berat daging lebih dari itu pengawetan hanya mampu bertahan 2 hari karena jumlah larutan pengawet sudah tidak mampu memusnahkan mikroba-mikroba yang ada.

\section{KESIMPULAN}

1. Dari hasil penelitian pada proses deproteinasi dengan konsentrasi pelarut 2,5 $\mathrm{N}$ dihasilkan kitin kotor seberat 32,5572 gram.

2. Pada proses deasetilasi dengan perbangdingan 1:15 (kitin bersih :pelarut) dihasilkan kitosan seberat 4,2511 gram. 


\section{DAFTAR PUSTAKA}

Hanafi, Muhammad, Syahrul Aiman, Efriana D., B. Suwandi. (2013). Pemanfaatan Kulit Udang untuk Pembuatan kitosan. Jurnal Sains Vol. 4 (2): 15-28

Hardjito L. (2009). Aplikasi Kitosan sebagai Bahan Tambahan Makanan dan Pengawet. Di dalam Prousiding Seminar Nasional Kitin Kitosan. Bogor: Departemen Hasil Perairan Fakultas Ilmu Perikanan dan Kelautan. Institut Pertanian Bogor

Hayashi, K. and Mikio,I. (2011). Antidiabetic Action of Low Molecular Weight Chitosan in Genetically Obese Diabetic KK-Ay Mice. Journal Biol Pharm Bull 25 (2): 188-192

Mekawati, Fachriyah, E. dan Sumardjo, D. (2012). Aplikasi Kitosan Hasil tranformasi Kitin Limbah Udang (Penaeus merguiensis) untuk Adsorpsi Ion Logam Timbal. Jurnal Sains and Matematika 8 (2) : 51-54

Mudjiman, A., 1982. Budidaya Udang Windu. Penebar Swadaya; Jakarta.

Synowiecky, J. And N.A. Al-Khateeb. 2003. Production, Properties and Some New Aplications of Chitin and Its Derivites. Journal Food Sci Nutr 43 (2): 145-171

Yunizal dkk, (2001), "Ekstraksi Khitosan dari Kepala Udang Putih (Penaeus merguensis)". J. Agric. Vol. 21 (3), hal 113-117. 